\section{Re: E-sigaretter - til skade eller nytte?}

Det har i Tidsskriftet gått en debatt i etterkant av T. K. Grimsrud og T. Sanners kronikk E-sigaretter - til skade eller nytte (1). Hele debatten kan leses på våre nettsider. Redaksjonen har blitt kjent med at en debattant i denne saken, Morten Moe, driver en blogg under navnet The Vaping Giraffe. På denne bloggen er det reklame fra forhandlere og produsenter av e-sigarettutstyr. Tidsskriftet følger internasjonal praksis i medisinsk vitenskapelige tidsskrifter, der alle forfattere fyller ut interessekonfliktskjemaet fra International Committee of Medical Journal Editors (ICMJE) (2). Moe har opplyst i sine debattinnlegg at han ikke har interessekonflikter. Etter redaksjonens mening er dette

en interessekonflikt som det burde ha blitt opplyst om.

Moe har blitt forelagt opplysningene, og skriver blant annet følgende $i$ en e-post til redaksjonen: «Det stemmer at jeg driver bloggen vapingiraffe.blogspot.no, og at det er noe reklame for forhandlere av e-sigaretter og dampeutstyr på bloggen. Dette er ment å dekke noe utgifter til å skrive produktomtaler. Jeg har imidlertid ikke hatt noe særlig inntekt på dette og kan nok i løpet av de snart to årene jeg har drevet bloggen telle hundrelappene på to hender.

Ingen av de produsentene eller forhandlerne det reklameres for påvirker hva jeg skriver på bloggen, hverken når det gjelder omtaler, politikk eller mine meninger om saken. De har heller ingen påvirkning på hvilke temaer jeg velger å skrive om. Dette gjenspeiler seg også i kritikken jeg gir produsenter jeg mener ikke tar sitt ansvar for produktsikkerhet på alvor. Bloggen ble startet for å fremme saken, og var i utgangspunktet uten reklame, men jeg valgte etterhvert å ha noe reklame der, som sagt for kanskje å kunne dekke noe utgifter til utstyr jeg ønsker å omtale. Imidlertid kan jeg trygt si at bloggen går godt $\mathrm{i}$ minus.»

Vi har viet stor spalteplass til denne debatten, og alle parter har hatt anledning til å ytre seg gjentatte ganger. Vi ser ikke at det kommer fram nye momenter nå, og setter derfor en strek for debatten i denne omgang.

\section{Redaksjonen}

Tidsskrift for Den norske legeforening

Litteratur

1. Sanner T, Grimsrud TK. E-sigaretter - til skade eller nytte? Tidsskr Nor Legeforen 2015; 135: 959-61.

2. http://tidsskriftet.no/Innhold/Forfatterveiledningen/Etikk-og-jus/ Interessekonflikter (16.11.2015).

\section{RETTELSE}

Lungekreft - insidens etter kjønn, alder og bostedsfylke $1984-2013$

Tom Kristian Grimsrud, Hans Kristian Skaug, Inger Kristin Larsen

Tidsskr Nor Legeforen 2015; 135: 1844-9

I Tidsskriftet nr. 20/2015 s. 1845 var det skjedd en fargeombytting i figur 1a. Dette er den korrekte figuren.

a Aldersstandardisert rate per 100000 menn Aldersstandardisert rate per 100000 kvinner
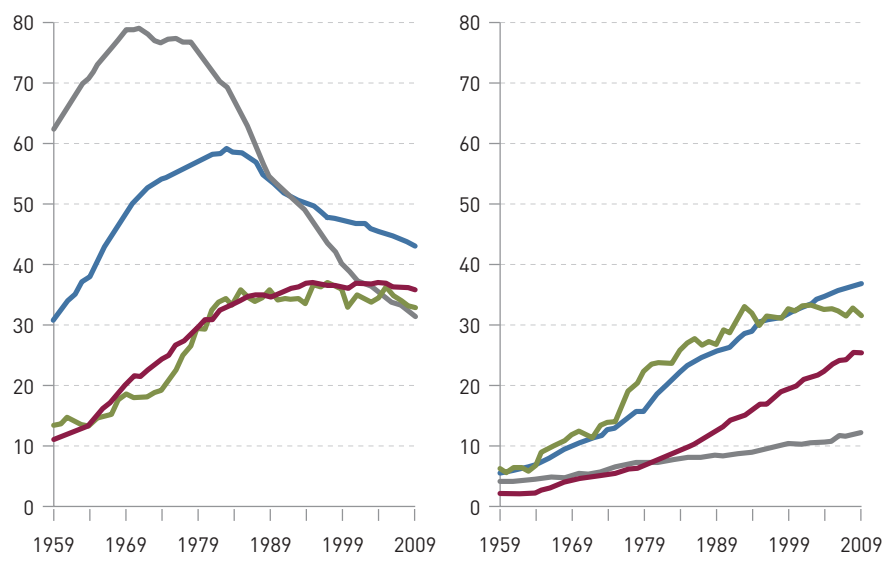

Danmark Finland Island Norge

Figur 1 Lungekreft i Finland, Danmark, Island og Norge. Insidensrater for a) menn og b) kvinner, aldersstandardisert i henhold til verdens standardbefolkning, glattet med femårige glidende gjennomsnitt. Data fra Sverige er utelatt fordi registreringen er forskjellig og ratene derfor ikke er sammenliknbare. Data fra NORDCAN (3)

Vi beklager feilen, den er rettet på nett. 